\title{
Primary Lymphedema: A Newborn Case
}

\author{
Primer Lenfödem: Bir Yenidoğan Vakası
}

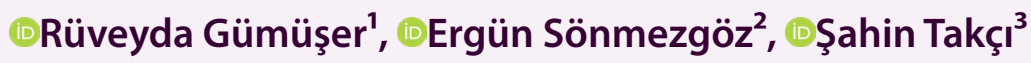 \\ ${ }^{1}$ Ankara Dr. Sami Ulus Obstetrics and Gynecology Child Health and Diseases Health Application and Research Center, Ankara, \\ Turkey \\ 2Department of Pediatrics, School of Medicine Gaziosmanpasa University, Tokat, Turkey \\ ${ }^{3}$ Divisions of Neonatology, Department of Pediatrics, Ondokuz Mayıs University School of Medicine, Samsun,Turkey
}

\begin{abstract}
Lymphedema is a condition characterized by generalization or regional accumulation of proteinrich interstitial fluid as a result of impaired lymphatic circulation due to congenital or acquired reasons. Lymphedema infection may occur as a result of secondary neoplasm, surgery, trauma, and radiation while most childhood cases are primary lymphedema. In cases of primary lymphedema, there is an erroneous development or function of the lymphatic system and most of them are thought to have a genetic predisposition. We aim to present a case of primary congenital lymphedema with a history of kinship between parents and no dysmorphic findings, born with lymphedema on both feet.
\end{abstract}

Keywords: primer lymphedema, edema on the dorsum of feet, newborn, lymphoscintigraphy

\section{ÖZ}

Lenfödem; lenfatik dolaşımın konjenital veya edinsel bazı nedenlere bağlı olarak bozulması sonucu, proteinden zengin interstisiyel sıvının jeneralize veya bölgesel olarak birikimiyle karakterize bir durumdur. Lenfödem enfeksiyon, neoplazm, cerrahi, travma ve radyasyona sekonder olarak gelişebilirken, çocukluk çağındaki olguların çoğu primer lenfödem şeklindedir. Primer lenfödem olgularında lenfatik sistemin hatalı gelişimi veya işlevi söz konusudur ve çoğunda genetik yatkınlık olduğu düşünülmektedir. Amacımız, anne baba arasında akrabalık öyküsü olan ve dismorfik bulguları olmayan, her iki ayak sırtında lenfödem ile doğan, bir primer konjenital lenfödem olgusunu sunmaktır.

Anahtar Kelimeler: Primer lenfödem, ayak sırtında ödem, yenidoğan, lenfosintigrafi

\section{INTRODUCTION}

Primary lymphedema is a disease that can manifest from the intrauterine period, characterized by edema that begins unilaterally or from the dorsum of both feet and can progress towards the lower extremity, developing due to developmental anomaly of lymph vessels (1). Primary lymphedema may be associated with genetic diseases such as trisomy $13,18,21$, primary congenital lymphedema, Turner syndrome, Noonan syndrome, lymphoedema-distichiasis, or yellow nail syndrome $(2,3)$. Milroy syndrome developing due to gene mutation should be considered $(4,5)$ as VEGFR-3 (FTL-4) with an autosomal dominant transition in cases with normal karyotype and positive family history, without syndromic findings. While primary lymphedema may be present from birth, it may occur later in the early period. Extremity involvement is unilateral or bilateral (6). Its timely diagnosis is especially important in order to prevent worsening of the situation in cases with visceral involvement. The purpose of treatment is based on preventing infections and complications that may develop. For this, the following are recommended: extremity involvement, exercise, massage, tightening bandage, and skincare (1). 


\section{CASE REPORT}

A male baby born from the fifth pregnancy of a fortyfour-year-old mother at 39 weeks of gestation, weighing $3490 \mathrm{~g}$ by cesarean section, was admitted to the neonatal intensive care unit because of respiratory distress in the delivery room and edema on the dorsum of both feet. It was learned that there was a second degree of kinship between the mother and father in the patient's family history, the mother has no miscarriage and stillbirth and that they have 4 healthy children. There was no known history of any major diseases or infections in the prenatal history, except dietary regulated gestational diabetes. The patient was on follow-up on physical examination and did not accompany dysmorphic findings. Although the baby was more prominent on the right foot and leg, there was bilateral edema extending towards the below-knee region on both feet (Figure 1, 2). When the family was questioned, it was learned that there were no family members with similar complaints. Complete routine blood count, biochemical parameters, and urine tests were normal in routine laboratory examinations and examinations for edema etiology. Albumin and protein values were normal. No pathological finding was detected in the chest $\mathrm{x}$-ray taken due to respiratory distress. Respiratory distress resolved in a few hours. Transfontanelle and all abdominal ultrasonography were normal. Echocardiography was normal. Arterial and venous colored Doppler ultrasonographies of bilateral lower extremities were also evaluated as normal in the examinations for the etiology of edema.

Lower and upper extremity lymphoscintigraphy was performed on the third day of his admission. In the lymphoscintigraphy images, it was observed that the radiopharmaceutical that was given on both upper extremities passed to the lymph node of the axillary; minimal transition to the inguinal lymph node was observed in the left lower limb and no transition to inguinal lymph nodes in the right lower limb. Primary congenital lymphedema was considered in the patient due to the absence of a significant transition on both lower extremities, especially on the right (Figure 3).

\section{DISCUSSION}

Lymphedema is characterized by a generalized or regional accumulation of protein-rich interstitial fluid (7) as a result of impaired lymphatic circulation due to congenital or acquired reasons. It can occur either primary or secondary in two ways. While lymphedema may develop secondary to different acquired factors (infection, kidney failure), secondary to neoplasm, surgery, trauma, and radiation; most childhood cases are primary lymphedema (8-10). Primary lymphedema is seen at a rate of $1 / 100,000$ (11). In primary lymphedema

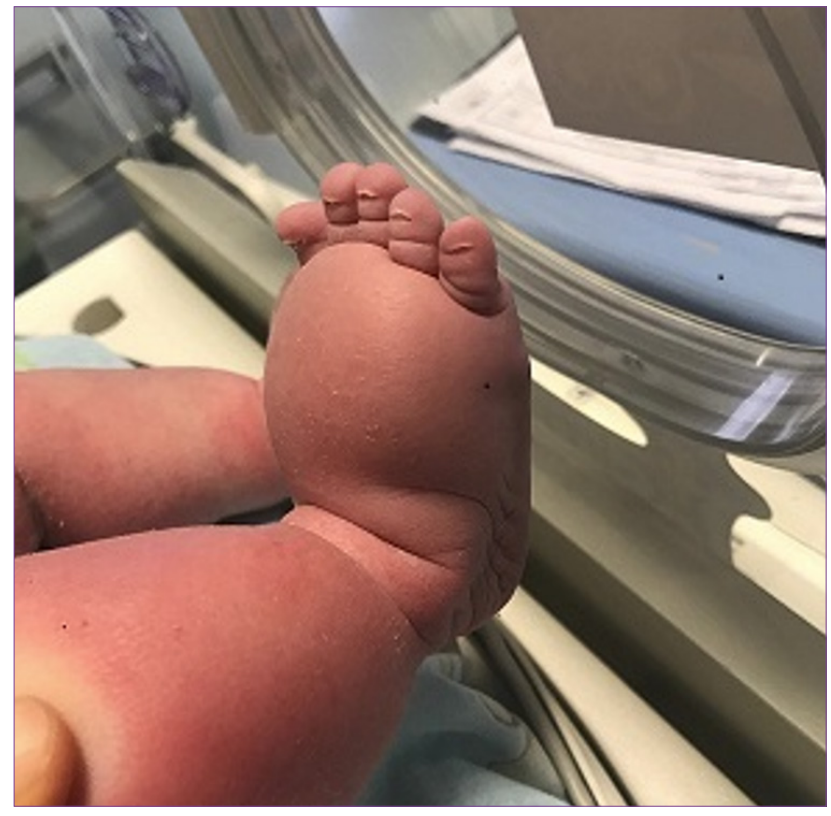

Figure 1.

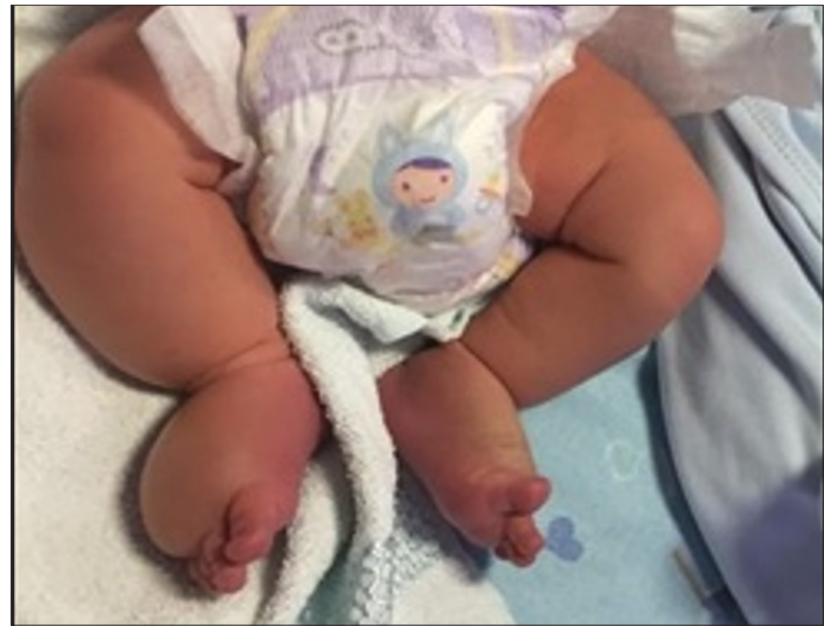

Figure 2.

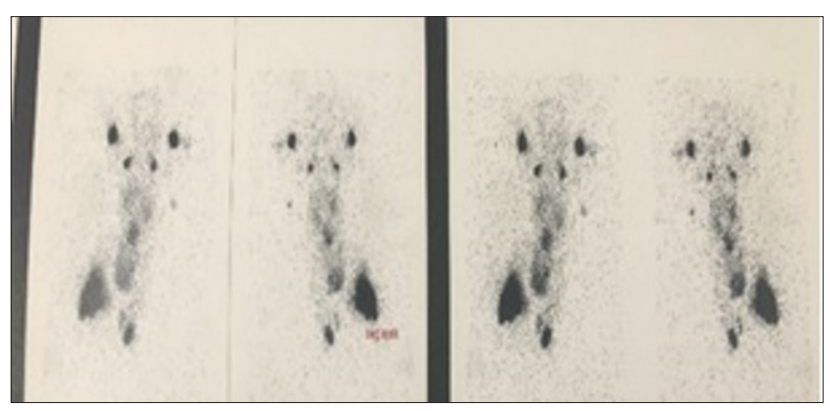

Figure 3.

cases, there is an erroneous development of lymphatic structures (aplasia, hypoplasia, dilatation) or function, and most of them are thought to be a genetic predisposition. Typically, asymmetrical and bilateral lower extremity involvement occurs while swelling can be seen in all extremities. VEGFR-3 (FLT-4), the gene of this disease, is located in the region of $5 q 34-q 35$ of the 
telomeric part of the $5 q$ chromosome (12). It genetically shows an autosomal dominant transition. While it can be seen in both sexes, it is more common in girls (13). Primary lymphedema may also be associated with genetic diseases such as trisomy $13,18,21$, primary congenital lymphedema, Turner syndrome, Noonan syndrome, lymphoedema dystiasis, or yellow nail syndrome $(2,3)$.

Most cases of lymphedema can be diagnosed by detailed history taking, physical examination, and ultrasonography. Lymphatic imaging is one of the examination methods used to confirm the diagnosis. Isotopic lymphoscintigraphy is considered the gold standard for the diagnosis of lymphedema since it is easy to use and minimally invasive, and is harmless to the lymphatic endothelium (14).

Treatment of primary lymphedema is conservative and generally successful in most patients. The main purpose of the treatment is to prevent the development of infections and complications related to edema. Elevation of the affected limb combined with skincare is sufficient for uncomplicated mild cases of lymphedema $(15,16)$. Over time, the subcutaneous tissue may harden due to protein accumulation and fibrosis in the extravascular area and hyperkeratosis may occur in the skin. The risk of cellulitis and lymphangitis increases with interruption of lymphatic drainage (17). Skincare reduces the risk of developing cellulitis and lymphangitis. In addition, compression bandages, manual lymphatic drainage (with special massage techniques), exercise, and strict diet (fluid and salt restriction) are other recommended treatment methods (18). In cases where medical treatment is unsuccessful, surgical intervention is among the treatment options (19).

Primary lymphedema was considered primarily due to lymphedema present from birth. Our patient was diagnosed with a clinical, physical examination, detailed history, and lymphoscintigraphy. The case is presented for a brief review of the primary lymphedema literature.

\section{ETHICAL DECLARATIONS}

Informed Consent: Written informed consent was obtained from all participants who participated in this study.

Referee Evaluation Process: Externally peer-reviewed.

Conflict of Interest Statement: The authors have no conflicts of interest to declare.

Financial Disclosure: The authors declared that this study has received no financial support.

Author Contributions: All of the authors declare that they have all participated in the design, execution, and analysis of the paper, and that they have approved the final version.

\section{REFERENCES}

1. Schook CC, Mulliken JB, Fishman SJ, Grant FD, Zurakowski D, Greene AK. Primary lymphedema: clinical features and management in 138 pediatric patients. Plast Reconstr Surg 2011;127(6):2419-31.

2. Noonan JA. Hypertelorism with Turner phenotype. A new syndrome with associated congenital heart disease. Am J Dis Child 1968;116(4):373-80.

3. Turner HH. A Syndrome of Infantilism, Congenital Webbed Neck, and Cubitus Valgus (Reprinted from Endocrinology, Vol 23, Pg 566574, 1938). Endocrinologist. 1995;5(5):330-8.

4. Brice G, Child AH, Evans A, et al. Milroy disease and the VEGFR-3 mutation phenotype. J Med Gen 2005;42(2):98-102.

5. Ghalamkarpour A, Holnthoner W, Saharinen P, et al. Recessive primary congenital lymphoedema caused by a VEGFR3 mutation. J Med Gen 2009;46(6):399-404.

6. Schook CC, Mulliken JB, Fishman SJ, Alomari Al, Grant FD, Greene AK. Differential diagnosis of lower extremity enlargement in pediatric patients referred with a diagnosis of lymphedema. Plast Reconstr Surg 2011;127(4):1571-81.

7. Brorson $\mathrm{H}$. Adipose tissue in lymphedema: the ignorance of adipose tissue in lymphedema. Lymphology. 2004;37(4):175-7.

8. Chiu TW. Management of secondary lymphoedema. Hong Kong medical journal = Xianggang yi xue za zhi. 2014;20(6):519-28.

9. Beloncle F, Sayegh J, Eymerit-Morin C, Duveau A, Augusto JF. AA amyloidosis as a complication of primary lymphedema. Amyloid. 2014;21(1):54-6.

10. Grada AA, Phillips TJ. Lymphedema Pathophysiology and clinical manifestations. J Am Acad Dermatol. 2017;77(6):1009-20.

11. Vignes S. [Lymphedema: From diagnosis to treatment]. La Revue de medecine interne. 2017;38(2):97-105.

12. Evans AL, Bell R, Brice $G$, et al. Identification of eight novel VEGFR-3 mutations in families with primary congenital lymphoedema. J Med Gen 2003;40(9):697-703.

13. Rudkin GH, Miller TA. Lipedema: a clinical entity distinct from lymphedema. Plast Reconstr Surg 1994;94(6):841-7.

14. Golueke PJ, Montgomery RA, Petronis JD, Minken SL, Perler BA, Williams GM. Lymphoscintigraphy to confirm the clinical diagnosis of lymphedema. J Vasc Surg 1989;10(3):306-12.

15. Badger CM, Peacock JL, Mortimer PS. A randomized, controlled, parallel-group clinical trial comparing multilayer bandaging followed by hosiery versus hosiery alone in the treatment of patients with lymphedema of the limb. Cancer. 2000;88(12):2832-7.

16. Warren AG, Brorson H, Borud LJ, Slavin SA. Lymphedema: a comprehensive review. Ann Plast Surg 2007;59(4):464-72.

17. Smahel J. Adipose tissue in plastic surgery. Ann Plast Surg 1986;16(5):444-53.

18. Badger C, Preston N, Seers K, Mortimer P. Physical therapies for reducing and controlling lymphoedema of the limbs. Cochrane Database Syst Rev. 2004(4):Cd003141.

19. Borman P. Lymphedema diagnosis, treatment, and follow-up from the view point of physical medicine and rehabilitation specialists. Turk J Phys Med Rehabil 2018;64(3):179-97. 